\title{
THE GREEK HOSPITAL AND PHARMACIES OF SMYRNA (1723-1922)
}

\section{GRČKA BOLNICA I LJEKARNE U SMIRNI (1723. - 1922.)}

\author{
Spyros N. Michaleas*, Theodoros N. Sergentanis**, \\ Aristeidis Diamantis ${ }^{* * *}$, Krystallenia Alexandraki $^{* * * *}$, \\ Lazaros Vladimiros ${ }^{* * * * * *}$
}

\begin{abstract}
SUMMARY
From the mid-1 $8^{\text {th }}$ century to the mid-20 ${ }^{\text {th }}$ century, Greek doctors in Smyrna collaborated with pharmacists, churches, and the city's Greek Orthodox community to create a stateof-the-art health network and charitable foundation to serve physical and mental health needs of the local community. At Graekikon Nosokomion o Agios Haralampos (Greek Saint Charalampos Hospital), or the Greek Hospital, every citizen, regardless of origin, language, religion, or economic status, had access to the most appropriate medical and pharmaceutical care. Neighborhood pharmacists complemented this care by administering vaccinations and
\end{abstract}

* Department of History of Medicine and Medical Ethics, Medical School, National and Kapodistrian University of Athens, Athens, Greece. ORCID: https://orcid.org/0000-0002$7507-8908$

** Department of Clinical Therapeutics, Medical School, National and Kapodistrian University of Athens, Athens, Greece. ORCID: https://orcid.org/0000-0002-9355-5528

***: Department of Cytopathology, Naval Hospital of Athens, Athens, Greece. ORCID: https:// orcid.org/0000-0001-5392-1194

***** Endocrine Unit, First Department of Propaedeutic Medicine, Medical School, National and Kapodistrian University of Athens, Athens, Greece. ORCID: https://orcid.org/0000-00032398-6768

****** Physician, Historian of Medicine, Athens, Greece.

Correspondence Address: Spyros N. Michaleas, Department of History of Medicine and Medical Ethics, Medical School, National and Kapodistrian University of Athens, Athens, Greece; E-mail: sp.michaleas@gmail.com. 
preparing medicines. Smyrna's pivotal influence on the Greek medical community ended in August 1922, when the Greek Hospital was destroyed during the Catastrophe of Smyrna.

Keywords: Greek Hospital of Smyrna, Pharmacies of Smyrna, Hospital of Saint Charalampos, George Moraitis

\section{INTRODUCTION}

As one of the most important cities of the Ottoman Empire, Smyrna had a pivotal role in the economy of the eastern Mediterranean. After the development of its port in the $17^{\text {th }}$ century, the population in Smyrna increased substantially. This increase had positive effects on the economy, but the constant influx of people also contributed to outbreaks of epidemic diseases, such as the plague, smallpox, and cholera. These epidemics prompted the establishment of hospitals in the city. One of the oldest hospitals and the first infirmary in the East was the Ospitalion, later named Graekikon Nosokomion o Agios Haralampos (Greek Saint Charalampos Hospital), or simply the Greek Hospital. The Greek Hospital also served as a charitable foundation, operated by Smyrna's Greek Orthodox community. Pharmacists in the area also had crucial roles in medical care, as they manufactured and distributed medicines. The Greek Hospital served the community for two centuries until it was destroyed during the Catastrophe of Smyrna in August 1922 (Dardalis, 2005; Vladimiros, 2008).

\section{The Greek hospital}

Despite its importance to the Ottoman Empire, Smyrna received little support for its health care. Various Christian communities in Smyrna thus founded and operated hospitals using contributions from wealthy citizens. First, the Dutch Hospital was founded in 1675 , followed by the Catholic Hospital in I7IO. When the Greek Hospital opened in I723, it was the largest and the finest hospital in the area (Argiropoulos, I995; Kostis, I905). In addition to these, the English, and the French, also had their hospitals in Smyrna (Atay, I978).

The house of Baroness Clara Catharina de Hochepied (I662-I733), a local widow known as Madame, was bought by the Greek community and converted into a hospital (later known as the Greek Hospital). During its first years of operation, the hospital was referred to as "the Inn" (Figures I, 2) (Argiropoulos, 1995; Solomonidis, 1955). The operating expenses of the hospital were covered by the Greek community. In I745, the financial difficulties of the Greek 
community led to the formation of the Brotherhood, led by the then Metropolitan of Smyrna Neophytos. Neophytos asked Christians to financially support the hospital, and many expatriates donated money. In particular, two merchants from Chios, Ioannis Mavrokordatos and Pantelis Sevastopoulos, financed a large renovation in 1748 . Sevastopoulos was named a benefactor for his donations. After the renovation, the hospital was renamed Graekikon (Argiropoulos, 1995).

It is worth noting that the notion of charity in western Europe was inextricably linked to Ottoman cities like Smyrna. According to Alexander and Laiou, the "merchants of Europe" were involved in funding and managing the Orthodox hospitals in Istanbul and other Ottoman cities like Smyrna (Alexander \& Laiou, 2014).

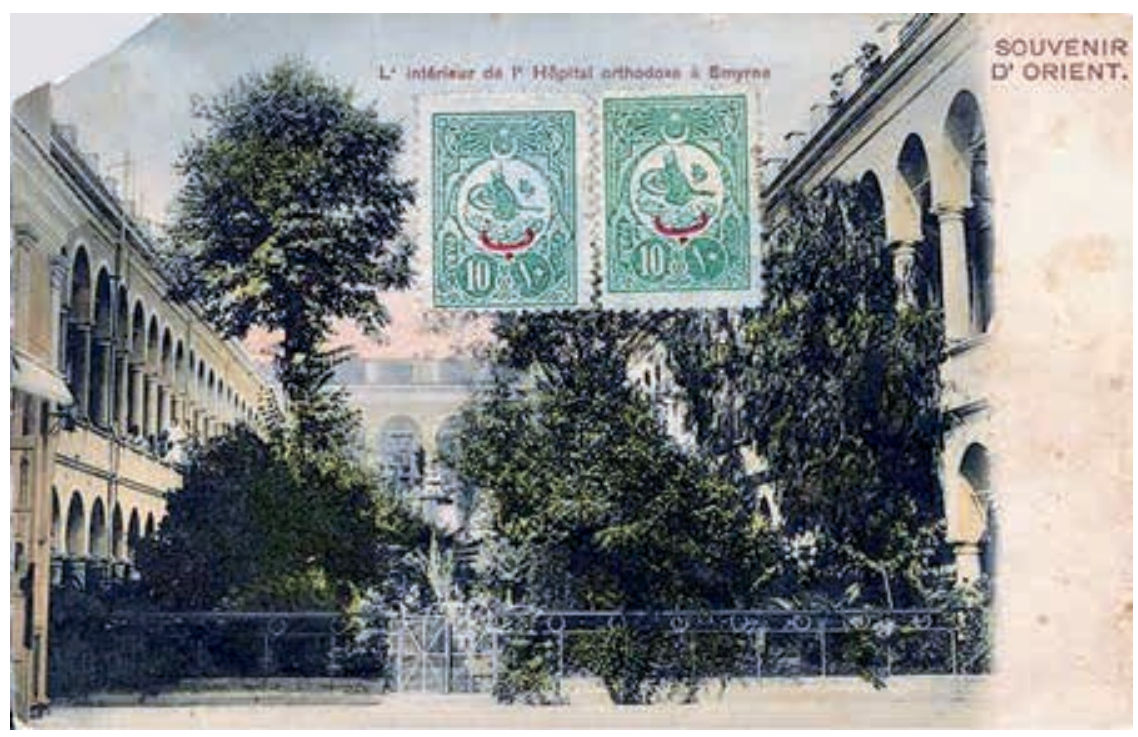

Figure r. The Greek Saint Charalampos Hospital. Source: Levantine Heritage Foundation.

In March 1797, the Greek hospital was destroyed in a fire during the Rebellion of Janissaries in Smyrna. Donations from Smyrna residents financed the new building, which included a courtyard providing a green space for them to enjoy, a laboratory, and specialized departments for treating patients with infectious diseases, the elderly, and the mentally ill. Treating the mentally ill as patients rather than criminals was an important advancement in the history of Greek medicine in Smyrna and around the world. According 
to the literature, a separate building for the care of the mentally ill was established in 1882 (Vladimiros, 2008). In I833, the church of Saint Charalampos was erected in the Greek Hospital's courtyard. Charalampos was an early Christian priest who was martyred in 202. He was condemned to death, at which time he prayed to God that the people living near his relics would never suffer famine or disease. His relics can be found throughout Greece, including Smyrna. Saint Charalampos protected the people of Smyrna from the plague (Argiropoulos, 1995; Clogg, I982; Karadimou-Gerolympou, 2000; Simopoulos, 1975).

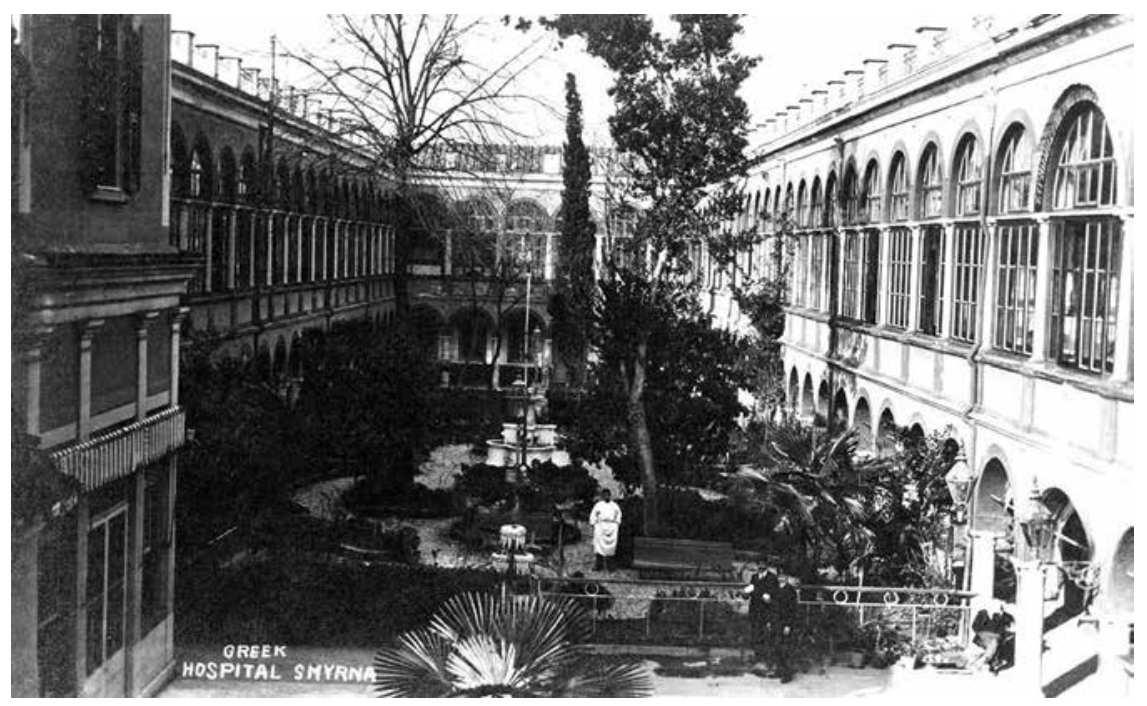

Figure 2. The Greek Saint Charalampos Hospital.

Source: Levantine Heritage Foundation.

In I893, a cholera outbreak was recorded in Smyrna. The Greek Hospital provided antiseptics for the disinfection of the houses and the grocery stores. In Igro, during another outbreak of the disease, the Greeks of Smyrna formed the "Solidarity Association", and with the assistance of the Greek Hospital, they established a first aid station inside the hospital (Solomonidis, 1955).

As the Greek Hospital grew in reputation and size, it adopted the latest technical advances in medical science. For example, the psychiatric department added a hydrotherapy clinic in 1882 at the cost of 2,000 gold pounds. Hydrotherapy was a new therapeutic method for the treatment of mental illness in Europe. In 1902, a foundling annex was added to care for abandoned infants. Prior to the establishment of the nursery, it was customary 
throughout Europe to give abandoned children to poor families, who would then raise them as their own, with financial support from the community. However, these children often became victims of neglect (Vladimiros, 2008). Hospital-based infant and childcare, financed by the city of Smyrna and its wealthy citizens, helped address this social problem. Medical supervision was provided by hospital doctors who offered their services for free (Vladimiros, 2008). During its first year of operation, the nursey housed 53 children, from newborns to 6-year-olds. By 1904, the nursery provided care to 73 children, and by 1905, more than 90 children were in its care (Anonymous, 1907). A microbiological laboratory, radiological department, and radiological machine were acquired in I9II (Haviara-Karahaliou, 2003).

Several publications in Greece and throughout Europe reported on the operation and success of the Greek Hospital, which served as a model for medical science throughout Ionia. People from all over Greece sought treatment there, as well as Turks, Armenians, Jews, and Catholics from other geographical regions (Vladimiros, 2008). In accordance with the mission of the Orthodox Church and the Brotherhood of Smyrna, all were accepted at the hospital for treatment. As the inscription on the hospital's main door read, "Knock, and it shall be opened unto you." From 1902 to 1903 , as an example of a typical year of operation, the hospital treated 2,297 patients and distributed free medicine to $\mathrm{II}, 8 \mathrm{O} 2$ people. The outpatient department performed between 60 and 70 wound treatments per day (Anonymous, 1907).

The leader of the ecclesiastical province, the Metropolitan of Smyrna, served as president of the hospital. The city of Smyrna financially supported its operations, mostly from wealthy citizens' donations. Other contributions came from fundraisers, lotteries, social events, real estate donations, corporate donations, and financial contributions from doctors. Wealthy citizens often named the hospital and education institutions of the community as beneficiaries in their wills. Donations from the poor also contributed to the hospital's financing (Tatakis, 1948).

By 1922, the hospital had acquired surgical, internal medicine, obstetrics, ophthalmology, infectious diseases, psychiatry, and nursery departments, along with microbiology and radiology laboratories. The last directors of the various departments of the hospital were Apostolos Psaltof (Figure 3) and Diogenes Nikolaidis (women's surgery), Alkiviades Doulgeridis and Konstantinos Konstantinidis (men's surgery), Stylianos Voronzeris (women's internal medicine), Panos Chronis (ophthalmology), Demetrios Stais (obstet- 
rics), Ioannis Hariatis (microbiology laboratory), Nikolaos Benakis (infectious diseases), and Solon Veras (foundling) (Vladimiros, 2008).
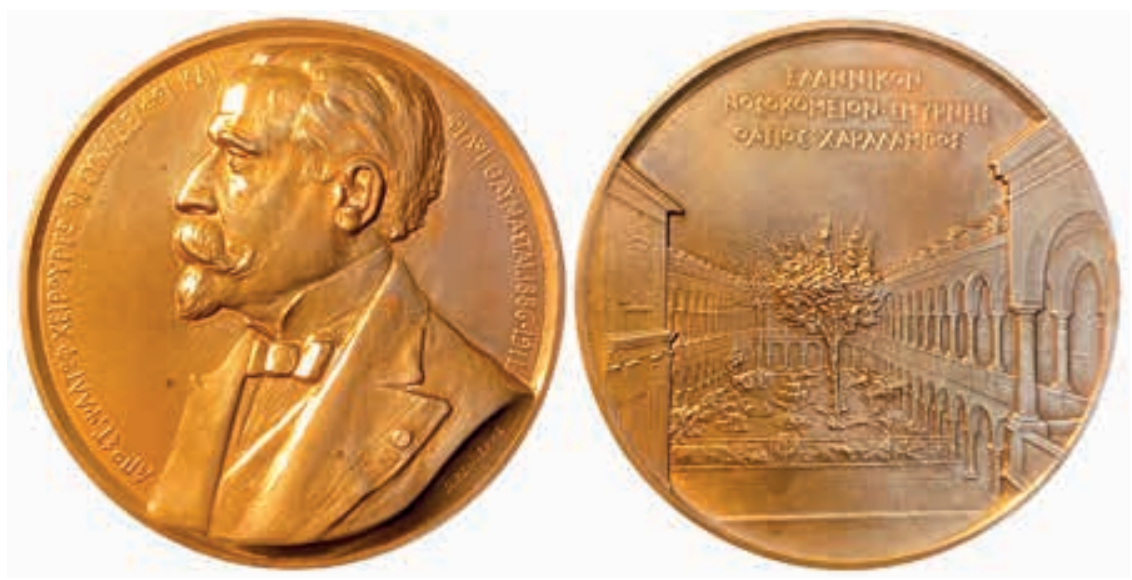

Figure 3. Greek commemorative bronze medal. Obverse: Bust of Apostolos Psaltof to left. Theinscription: AПО

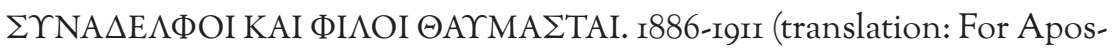
tolos Psaltof surgeon, the colleagues, friends, and fans I886-IgII). Under the bust the name of the die-cutter, П. PENIEPH $\Sigma$ (P. Renieris). Reverse: Depicted is the Greek hospital in Smyrna with its gardens. The inscription:

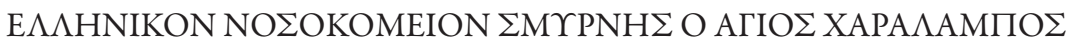
(translation: The Greek hospital of Smyrna, Saint Charalampos).

When the Greek Hospital was burnt down during the Catastrophe of Smyrna in I922by the Turks, Director Michalis Isaias transferred the patients safely to the Dutch hospital. The locking of the hospital, prior to its destruction, represented an act symbolizing the end of the Greek cultural presence in Smyrna.

\section{The Greek Pharmacies of SMyrna}

During the first half of the roth century in Smyrna, there was much overlap in the duties of the physician, the drug maker, and the drug seller. Few doctors had private consulting offices; some doctors owned pharmacies, but many more were 'linked' to specific pharmacies where patients knew they would find them. This pattern was also present on Chios Island in the early decades of the 2oth century (Michailidis, 2002). 
Pharmacies in Smyrna also served as a place for doctors and scholars to discuss various social, literary, and philosophical topics. Smyrna's pharmacists and doctors were esteemed for their scientific expertise, social contributions, and formal studies at universities in Italy, France, Germany, and Austria. Diary entries of that time described the pharmacy as a "doctor's meeting place". One of the most famous of these was Dimitrios Argiropoulos' pharmacy, where prominent Greeks, such as Marinos Koutouvalis, Georgios Latris, Michail Tsakiroglou, and Miltiades Emmanouil, met to discuss political, scientific, literary, and social topics (Vladimiros, 2008).

Patients often visited the pharmacy that their doctor frequented to have a consultation. If the doctor was absent or the patient could not get out of the house, they left a note, and the examination was carried out at home. In some pharmacies where a lot of doctors provided their services, they made sure to arrange the time slots, so that there was always a doctor in the pharmacy to help the patients (Vladimiros, 2008).

An 1825 document lists the refugees that arrived in Nafplio during the Greek Revolution, including their names, professions, and places of origin. This list mentions Vasilios Dragonieus and Charalampos Sardinalopoulos as two pharmacists from Smyrna (Anastasiadis, 196r). A professional guide of Smyrna in 1875 lists 33 pharmacies, of which 24 belong to Greeks. Each pharmacy lists the doctor who provides services there. An 1896 ad for Koutsaftopoulos pharmacy lists 15 physicians available to examine patients. A 1920 trade guide from Smyrna lists 66 pharmacies in the city, of which at least 33 appear to have been owned by a Greek, as indicated by the name of the pharmacist.

As the field of microbiology began to develop in the late igth century, pharmacists and other scientists began conducting various hematological, biochemical, and microbiological testing. For example, the historian Socrates Prokopiou mentions the chemist and microbiologist, Tasos Argiropoulos.

Some of the well-known pharmacists were Dimitrios Konstantinidis, Konstantinos Koutsautopoulos, Stefanos Stais, Konstantinos Georgiadis, Dimitrios Argiropoulos, and Nikolaos Argiropoulos (Anastasiadis, I940; Vladimiros, 2008). As mentioned above, several doctors in Smyrna also operated a pharmacy; Galinos Klados, Themistocles Saverios, Georgios Ioannidis, Themistocles latros, and Christodoulos Koutouzis, provided vaccinations, basic surgeries, and first aid treatments either at the pharmacy or in the patients' homes. The School of Medicine at the National University of Athens trained many doctors and pharmacists from Smyrna, including Kon- 
stantinos Katakouzinos, its first graduate pharmacist in 1867. Dimitrios Konstantinidis followed in 1884 and Nikolaos Argiropoulos in I889 (Vladimiros, 2008).

George Moraitis' pharmacy is a special case. Moraitis was born in Skiathos in 1873 . He studied medicine in Constantinople and received his diploma in I895. He settled in Smyrna and worked for a short time in the pharmacy of Panagiotis Chionis. He was Chief Pharmacist at the Ottoman Hospital in Smyr-

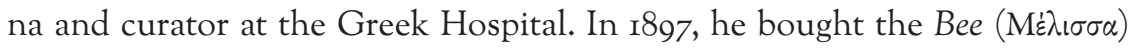
pharmacy, which was owned by Sklavos, and renamed it to Moraitis Pharmacy. The three-story pharmacy employed I2o people and had special departments for medicines and medical equipment, dental and surgical supplies, cosmetics, perfumes, furniture, corsets, and herbs, as well as chemical and microbiological laboratories. In I9I9, he organized a publicly funded food dispensary for the poor with Apostolos Psaltof, Dimitrios Ioakimidis, and Socrates Solomonidis. Moraitis Pharmacy was destroyed during the Catastrophe of Smyrna in 1922. Moraitis then built a similar pharmacy in Alexandria, Egypt, where he died in 1953. (Figure 4)

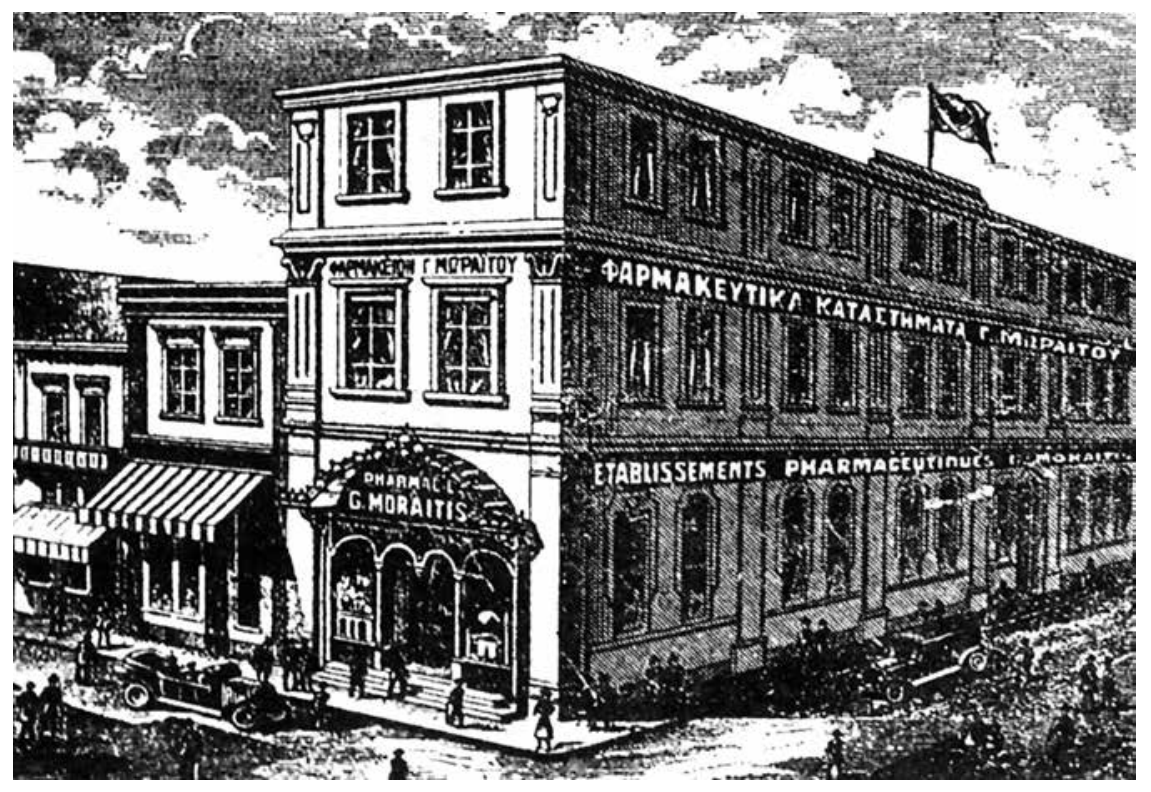

Figure 4. The pharmacy of George Moraitis. Credits: Vladimiros L. The History of Greek Medicine in Smyrna [in Greek] (Athens: The Association of Smyrnaeans, 2008). 
In 1909, the pharmacists of Smyrna founded the Pharmaceutical Association of the Smyrnaeans. In 1915, the only Turkish pharmacist in Smyrna demanded that the association's proceedings be written in Turkish. Numerous Greek pharmacists in Smyrna denied this request, and the association disbanded (Solomonidis, 1955).

As medicine became further specialized at the turn of the century, physicians gradually switched to using their own private consulting rooms with the necessary tools for examining patients. Paraclinical exams continued to be performed at pharmacies in Smyrna until 1922.

\section{CONCLUSION}

The wealthy Greeks of Smyrna helped develop vital health infrastructures, such as hospitals and pharmacies. Among the most important health institutions was the Greek Hospital of Saint Charalampos. Pharmacists and doctors collaborated closely to provide fast and efficient health services. Together, these professionals played crucial roles in setting a basis for the modern health care systems in the context of interdisciplinary collaboration.

\section{Conficts of interest}

The authors have no conflict of interests to disclose.

Funding sources

No funding sources need to be credited.

\section{REFERENCES}

1. Alexander, J. \& Laiou, S. (2014). Health and philanthropy among the Ottoman Orthodox population, eighteenth to early nineteenth century. Turkish Historical Review, 5(1), 1-15.

2. Anastasiadis, G. (1961). The repetition of history [in Greek]. Asia Minor Chronicles, 9, 116-127.

3. Anastasiadis, G. (1940). The contribution of Asia Minor people to the national rebirth [in Greek], Asia Minor Chronicles, 3, 213-232.

4. Anonymous. (1907). The Greek Nursery school [in Greek]. Athens.

5. Anonymous. (1907). The Greek Hospital [in Greek]. Athens.

6. Argiropoulos, G. (1995). The Greek Hospital of Smyrna "Saint Charalampos" [in Greek]. Deltos, 9, 3-5.

7. Atay, Ç. (1978). Tarih içinde Izmir [Izmir in History]. Izmir.

8. Clogg, R. (1982). The Smyrna 'rebellion' of 1797: Some documents from the British archives. Bulletin of the Centre for Asia Minor Studies, 3, 71-125. 
9. Dardalis, N. (2005). Greek Hospital of Smyrna. In Encyclopaedia of the Hellenic World - Asia Minor, http://constantinople.ehw.gr/forms/fLemmaBodyExtended.aspx?lemma$\mathrm{ID}=4037$

10. Haviara-Karahaliou, S. (2003). Folk medicine for the eyes and other texts [in Greek]. Chios: Chios Medical Society.

11. Karadimou-Gerolympou, A. (2000). Searching for lost century in the territorial evolution of Smyrna [in Greek]. In M. Stefanopoulou (Ed.), Hellenism from abroad: Constantinople and Smyrna 1800-1922 [in Greek] (pp. 269-294). Athens: Society for the Study of Modern Greek Culture and General Education.

12. Kostis, N. (1905). The first orthodox hospital in Smyrna [in Greek]. Xenofanis, 2, 254-269.

13. Michailidis, A. (2002). Cum Deo-Medicine in Chios island during the first half of the $20^{\text {th }}$ century [in Greek]. Chios: Aegeas.

14. Simopoulos, K. (1975). Foreign travelers to Greece [in Greek]. Athens.

15. Solomonidis, C. (1955). Medicine in Smyma [in Greek]. Athens.

16. Tatakis, V. (1948). A will from 1812 [in Greek]. Asia Minor Chronicles, 4, 82-83.

17. Vladimiros, L. (2008). The History of Greek Medicine in Smyrna [in Greek]. Athens: The Association of Smyrnaeans.

\section{SAŽETAK}

Od sredine I8. do sredine 20. stoljeća grčki liječnici u Smirni surađivali su s farmaceutima, crkvama i gradskom grčkom pravoslavnom zajednicom kako bi stvorili najsuvremeniju zdravstvenu mrežu i dobrotvornu zakladu koja će služiti fizičkim i mentalnim zdravstvenim potrebama lokalne zajednice. U Graekikon Nosokomion o Agios Haralampos (grčka bolnica Saint Charalampos), ili Grčkoj bolnici, svaki je građanin imao pristup najprikladnijoj medicinskoj i farmaceutskoj skrbi bez obzira na podrijetlo, jezik, vjeru ili ekonomski status. Farmaceuti u kvartovima nadopunili su tu skrb cijepljenjem i pripremanjem lijekova. Ključni utjecaj Smirne na grčku medicinsku zajednicu završio je u kolovozu ig22. kada je grčka bolnica uništena tijekom katastrofe u Smirni.

Ključne riječi: grčka bolnica u Smirni, ljekarne u Smirni, bolnica Saint Charalampos, George Moraitis 